\title{
Economic Studies on the Production of Fruit Juice from a Locally Sourced Fruit 'African Star Apple'
}

\author{
Oseni Kadiri $^{1 *}$, John Temitope Kolawole ${ }^{2}$, Babatunde Olawoye ${ }^{1}$, Alasa Paul Kadiri ${ }^{3}$ \\ ${ }^{1}$ Department of Food Science and Technology, Obafemi Awolowo University, PMB 13, Ile-Ife, Nigeria
}

${ }^{2}$ Department of Building Technology, Obafemi Awolowo University, PMB 13, Ile-Ife, Nigeria

${ }^{3}$ Department of Human Resource Management, University of Benin,P.M.B.1154,Benin City, Nigeria A R T I C L E I N F O \begin{abstract}
A B S T R A C T
The economic evaluation for the production of fruit juice from the Africa star apple otherwise known as 'Agbalumo' in the south western part of Nigeria was evaluated using the NPV (Net Present value) and IRR (Internal Rate of Return) methods assuming a uniform cash flow over a 10-year plant life. Sensitivity analysis was conducted by varying the number of production days (330, 300 and 250 days) at $100 \%$ plant capacity and varying the plant capacity $(100,85$ and $70 \%)$ for a 330-day production schedule. Some components of the operating cost reduced with number of days and plant capacities. The production cost and product cost per unit increased with either plant capacity utilization or the number of days. It was observed that product cost/ $500 \mathrm{ml}$ Tetra Pak of Agbalumo juice at $85 \%$ and $70 \%$ stood at $\$ 37.48$ while payback time/profitability percent had better index at 300 and 250 days compared to 330 days of plant operation. The results further indicated that the plant should not be operated for less than 250 days and plant capacity utilization of $70 \%$ in the year. Flexibility in the plant capacity utilization in the range of $70 \%-85 \%$ for 330 days shows a good economic performance as well as result of the NPV and IRR for this operating condition.
\end{abstract}

Article history:

Received 25 September 2015

Accepted 23 June 2016

Available online, ISSN: $2148-127 \mathrm{X}$

Keywords:

African star apple

Agbalumo

Net present value (NPV)

Internal rate of return (IRR)

Plant capacity utilization

${ }^{*}$ Corresponding Author:

E-mail: kadirioseni@yahoo.com

\section{Introduction}

African Star apples popularly known as 'Agbalumo' in the south western part of Nigeria are common plant found growing in the wild and cultivated in the southern part of Nigeria. Botanical name is Chrysophyllum albidum, a wild tropical tree belonging to the Sapotacae family can be find in diverse eco-zones in Nigeria and in other tropical African countries such as Uganda, Niger Republic, Cameroon and Cote d'Ivoire (Adewusi and Bada, 1997). It's a dark yellowish fruit with semi-circular seeds, a popular seasonal fruit normally consumed with its pericarp in the West Africa region. The fruit is mostly cultivated in the rural areas and is very common during the months of December to April. This wonderful fruit is picked by Africans on their way to the farm, during the era of our forefathers. But nowadays, it can be gotten mostly at the marketplace as it has become a source of income to the people mostly living in the rural areas. During African star apple season, you will see both adult and children savoring the great taste of this indigenous fruit. It has good flavour and is source of vitamins $\mathrm{C}$ (more than oranges/guava), minerals, calcium, iron and fiber (Chukwumalume et al., 2010). It is called cherry by English natives, Agbalumo in the Southern-western part of Nigeria, Udara in the Eastern part of the country and
Otien in Edo state. Ureigho and Ekeke (2010) estimated the proximate composition of Africa star apple to be in the range of $11 \%$ carbohydrate, $4 \%$ crude fiber, $3 \%$ Lipids ,7 \% protein ,Calcium (17.11 ppm), Iron (<1 ppm), phosphorus (9.92 ppm), vitamin C (25.03 ppb), vitamin A $(10.74 \mathrm{ppb}), \quad \mathrm{B} 1$ and B2 $(<1 \mathrm{ppb})$. The study recommended that the awareness of the nutritive value of this species be increase so as to encourage its consumption as food supplement and utilization. International center for research in agro-forestry (ICRAF, 2007) noted that the fleshy and juicy fruit which is popularly eaten is a potential fruit source for soft drink production. The fruits are also suitable for the production of fruit jams and jellies (Ureigho and Ekeke, 2010). Ajewole and Adeyeye (1991) reported that the juice of the fruit has potentials as an ingredient of soft drinks and can be fermented for wine or other alcohol production while Adepoju et al. (2012) observed African Star Apple to be high in micronutrients of nutritional importance, low in gross energy, sodium and antinutrients, and possess excellent values of index of nutritional quality and suggested that their consumption by the populace should be encouraged and promoted where and when the fruit is available. 
Appropriate packaging, in addition to its role of providing a means of delivering product, maintains commercial sterilization of the product and barrier to several hazards (Cabes, 1985).). Although, the practice of sterilization of foods in hermetically-sealed metal containers has been in used for a long time and has extensively been studied, development of economical technologies that directly reduced energy consumption is important to food processors. Improved packaging materials, containers, and methods are continually being developed in order to obtain thermo-stabilized products of better quality (Abou -Fadel and Miller, 1983). Tetra Pak company, since its founding by Mr. Ruben Rausing in the early 1950s, has grown into being one of the largest carton package manufacturer companies in the world. The initial company's objective was to replace bulk selling of goods with consumers adapted carton based packaging for flour, sugar, salt and later on milk and juice. It established itself on the market as one of the first carton packaging companies for milk. Tetra Pak's early involvement in both the required machinery for packaging and filling as well as the development of the packaging material has given it a unique roll on the global market. Today, Tetra Pak produces a wide range of package for many different contents as well as filling machines that are used to fill the packages with their content and seal. By manufacturing the packaging material, the filling machines as well as downstream equipment, Tetra Pak can ensure costumer full control of both the filling and the packaging process.

The nutritional and health benefits of this fruit, their availability especially in rural areas and low cost make them a good food product that can be formulated into fruit juice in improved pack. It is also a widely acceptable local fruit, hence its processing into a juice would gain wide acceptance from locals and city dwellers. Likewise, there is scarcity of documented record of its juice or juice blend; hence, this study will be the first of its kind. The aim of this study is to determine the cost, feasibility and profitability of setting up an Agbalumo fruit juice company in the southern part of the Nigeria where the fruit is mainly found. In order to achieve this objective, a comprehensive cost list of setting up the production of this juice in Tetra Pak comprising of plant layout ,machinery, raw materials, running cost and personnel cost has been included in this report analysis.

\section{Materials and Method}

Economic evaluation for the production of Tetra Pak packaging system of the juice was based on the establishing processing conditions of United Nation Industrial Development Organization (UNIDO), technological manual (2004) on small scale fruit and vegetable processing and products with modifications. The basis of production was based on constant mass flow rate from the automated filling chamber compartment with an angular speed of 60 tetra pack per min having a net volume of 1 liter per Tetra Pak. Costs were based on the level of output for an industrial plant working one shift at 8-hours for 330 days per annum (Moresi, 1994). A plant service life of 10 years was assumed (Akanbi and Taiwo, 1999). The cost of purchasing new equipment (Table 1) was based on recent data from varieties of equipment manufacturers, suppliers and also information from design engineers, technologists, equipment journals and the internet. Two electricity generating units were included among the equipment required due to the irregular and unstable power supply from the national grid. One hundred liters of diesel estimate at $\$ 145$ per liter would be required per day for the running of the generating set. Fixed capital was estimated using the factorial method as a function of the total purchased cost of the major equipment items required for process as described by Coulson and Richardson (2005) and Peters et al.(2003). This includes the costs of ancillary installations, instrumentation, piping and valves, painting, electrical plants, civil works, provision of utilities and services, design and engineering, contractors' fees and contingencies (Zacharias and George 2008).

Operating costs i.e. the cost of producing the product was evaluated from the flow diagram in Figure 1 and Table 1 and this included raw materials and services requirements while the capital cost estimates were as described by Coulson and Richardson (2005) and Peters et al. (2003). Table 2 gives the essential materials required to manufacture the product. The quantities required were multiplied by the operating hours per annum to get the annual requirements. The current prices of the raw materials (obtained from the local market and imported items) fluctuate with product availability and exchange rate of dollar. An average price was gotten by considering the price difference of fresh Agbalumo fruit at times of scarcity and harvest. Cost estimates of \$32/unit were obtained for a one liter Tetra Pak packaged. The price of the distribution shrinks pack $\left(0.5 \mathrm{~m}^{2}\right)$ was estimated as $10 /$ unit, which would contain 10 units of the 1 liter Tetra Pak. Furthermore, the price of a carton was arrived at 12/unit. The term utilities include power, steam, diesel etc. Energy consumption (kWh per 8 -h shift) for the processing is described in Table 1 . Electrical ratings specified by the manufacturer and the current power rate charge per $\mathrm{kWh}$ were used in calculating electrical energy use. Steam requirements, where necessary, were calculated from manufacturer's information and expressed as $\mathrm{kWh}$. The national rate for industrial users supplied by the Power Holding Company of Nigeria was used (power at $\$ 23 / \mathrm{kWh}$ ). The labour costs were evaluated based on the Nigeria labour requirements, qualification, experience with similar processes and current wage levels was used. The new minimum wage rate by the Nigerian Labour Congress (NLC) with the agreement of National Association of Food Tobacco and Beverages Employees for (NAFTBE) allowances applicable in the Nigerian food industries (as of 2015) were $18,000 /$ month for the factory worker (to which other packages are added by my analysis to make amount payable "non-tax" 118,500 ), \# 24500 for technical operators and $\$ 36500$ for supervisors per month respectively. Table 1 shows the number of factory 
operators required per unit of equipment per operation, while the supervisors are selected for every 4 operators (Coulson and Richardson, 1983). Maintenance cost per annum was evaluated at $10 \%$ of fixed capital, while straight line depreciation was used to calculate plant depreciation expense over a 10-year period (Lin et al., 2014). Zero salvage value was assumed for the equipment at the end of its operation life (Zacharias and George 2008). Other general expenses including taxes, insurance, capital charges, royalties, sales expenses, general overheads, etc. were taken into consideration as reported by Zacharias and George (2008). The selling price of the processed product was estimated as cost price plus $30 \%$, $40 \%$ and $50 \%$ profit. Expected annual sales were obtained by multiplying the selling price with the number of units produced (Tang et al. 2016).

The price of a unit product was obtained by dividing the total operation cost by the number of units produced per annum. Sensitivity analysis of the product price as a function of the number of operating shifts/day was also tested using procedures described by Taiwo et al. (1997).
This was achieved by varying the number of production days $(330,300$ and 250) and plant utilization capacity $(100,85$ and $70 \%)$ to examine the effects of uncertainties and forecasts on the viability of the project. Fixed capital and some variables operating costs which are a function of fixed capital remains the same irrespective of the number of production days or plant utilization. Other cost such as raw materials and utilities etc. increased as the number of shifts increased.

Procedures described by DeGarmo et al. (1979) and Barry et al. (1983) were used to analyze the economic feasibility of this project using the net present value (NPV) and the internal rate of return (IRR). These methods were chosen because they directly account for the time value of money and have superior analytical methods (Barry et al., 1983). Cash flows were assumed to be uniform throughout the plant life. The minimum attractive rate of return (M.A.R.R.) was taken as the minimum bank interest rate of $20 \%$. Table 3 shows how the cash flow was arrived at.

Table 1 Estimates of major equipment and costs of processing Africa star apple fruit juice in Tetra Pak

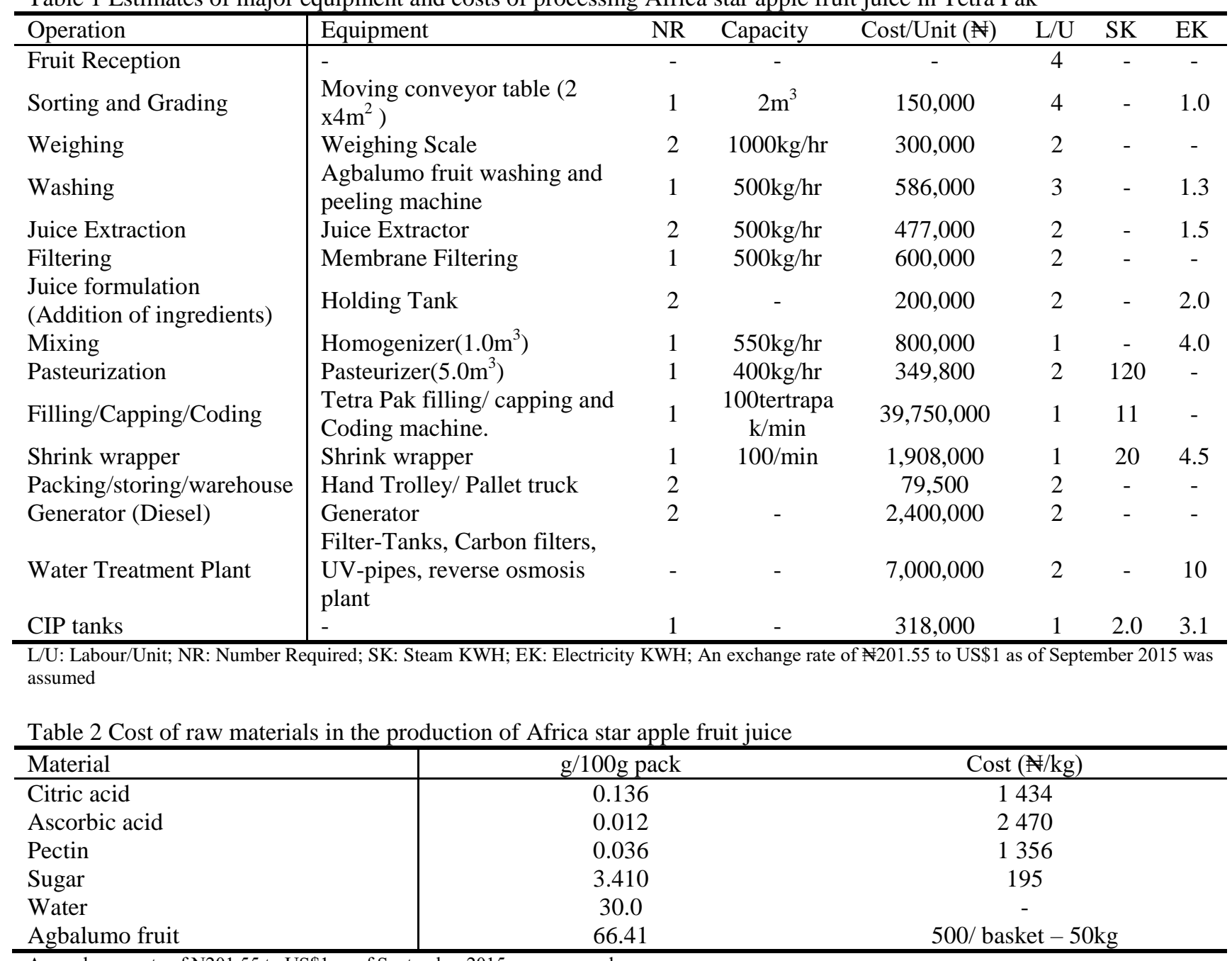

An exchange rate of $\$ 201.55$ to US\$1 as of September 2015 was assumed 
Table 3 Procedure for economic analysis ${ }^{1}$

\begin{tabular}{c|lc}
\hline S/N & \multicolumn{1}{|c}{ Parameter } & Analysis \\
\hline $\mathrm{a}$ & Sales & $N \times$ units $/$ day $\times$ operatingdays \\
$\mathrm{b}$ & Operating costs & Annual production cost \\
$\mathrm{c}$ & Profit & $(a-b)$ \\
$\mathrm{d}$ & Depreciation & $10 \%$ of depreciable fixed asset \\
$\mathrm{e}$ & Before tax earning $=$ taxable value & $c+d$ \\
$\mathrm{f}$ & Tax & $30 \%$ of e \\
$\mathrm{g}$ & Cash flow & $f-h$ \\
\hline
\end{tabular}

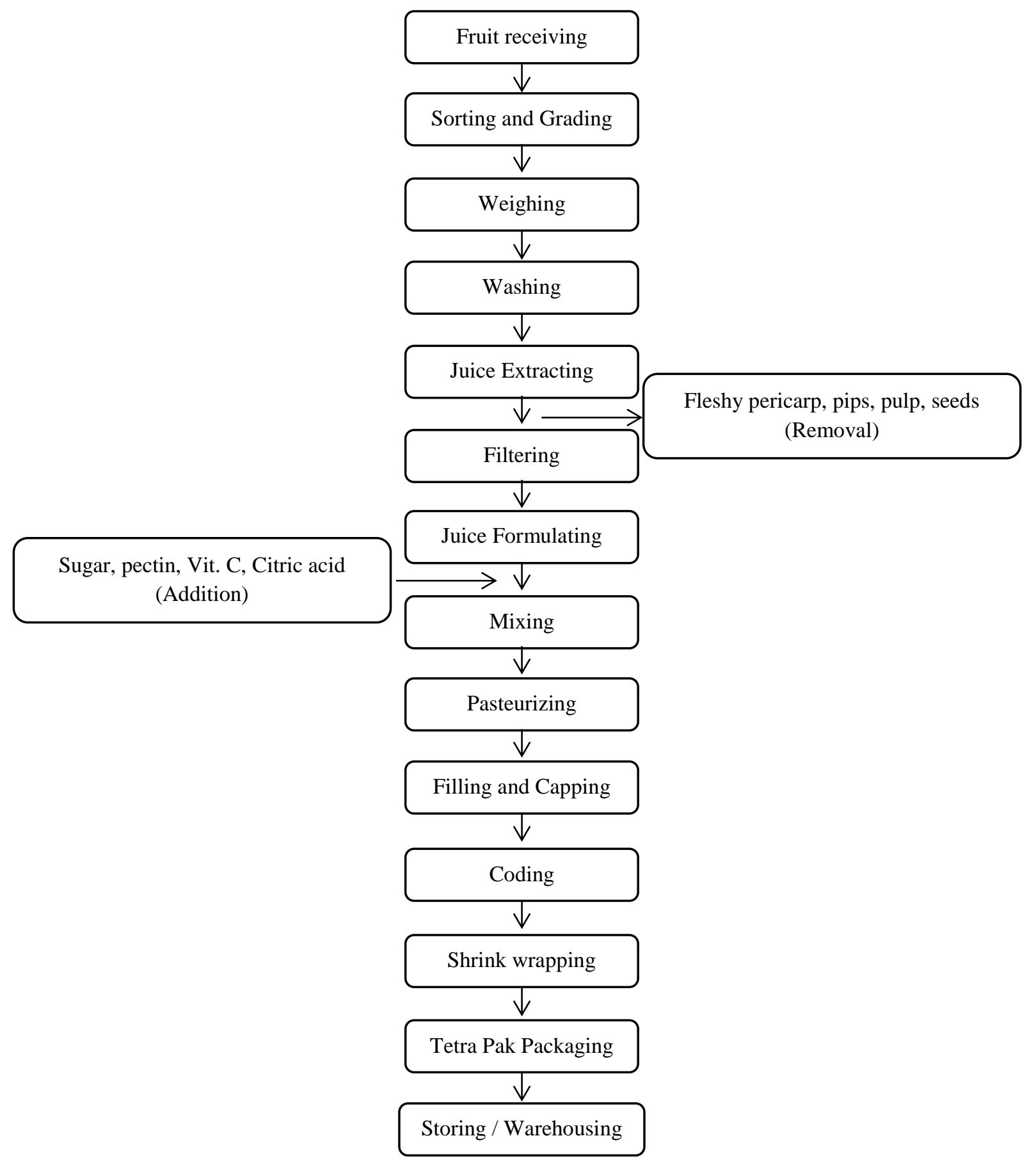

Figure 1 Flow diagram for the production of African Star Apple Fruit Juice in Tetra Pak 
NPV was estimated using Equation (1) for uniform series of payment.

$$
N P V=-\operatorname{Inv}+A\left[U_{S P V}, N\right]+V_{N} /(1+i)^{N}
$$

Where Inv is the initial investment, $\mathrm{A}$ is the annual cash flow, $\mathrm{i}$ is the interest rate or discount rate, USPV is the uniform series of payment value, $\mathrm{N}$ is the plant life, and $V_{N}$ is the salvage value for the equipment. Since the salvage value for the equipment is zero, then Equation (1) becomes

$$
\mathrm{NPV}=-\operatorname{Inv}+\mathrm{A}\left[\mathrm{USPV}_{\mathrm{i}, \mathrm{N}}\right]
$$

USPV is found by using the appropriate uniform series table at the desired interest rate (Tables E-1 to E-20 in DeGarmo et al., 1979). The internal rate of return (IRR) is that rate of interest that equates the NPV of the projected series of cash flow payments to zero. To find IRR for investment, NPV was set equal to zero, and then solved for i, i.e.

$$
0=-\operatorname{Inv}+\mathrm{A}\left[\mathrm{USPV}_{\mathrm{i}, \mathrm{N}}\right]
$$

\section{Result and Discussion}

The summary of the economic analysis for the production of Agbalumo fruit juice in $500 \mathrm{ml}$ Tetra Pak in Nigeria was analyze and presented in Table 4 and Table 5. The estimated fixed capital that will be required for the setting up production was estimated to $2.71 \times 10^{8}$ naira which is inclusive of the cost of the major equipment that is needed for the production process. Table 4 and Table 5 project the operating costs for different days per year and at utilization capacities. Even though Table 4 reflected a high NPV and IRR value for 330 days of production and $100 \%$ capacity which reduces the unit cost of a Tetra Pak of Agbalumo juice, it's too early to assume that a newly constructed industrial production plant should be operated at that capacity and number of days. The reason was that the fruit, which is the major raw materials for the production for the juice is not readily available all year making it difficult to source at certain times of the year. Also the need to test the market acceptance and quantity of the juice products the market can take is another factor. Operation at $70 \%$ capacity utilization for 8 hours a day in the beginning of operation will be more profitable to give room for efficient sales and marketing of produced juice while avoiding wastage. However, a 5\% annual increase in capacity utilization should be assumed depending on market factors. Expansion to a higher capacity can be considered later and will mainly be dictated by the level of business performance and sales. At plant operation for 330 days at $100 \%$ capacity, utilities consumption which constitute mainly of power is $1.03 \%$ of the annual operating cost. The high cost of energy is a reflection of the high energy utilization in the production process and the need to take this into utmost consideration before the setting of the production plant. While the major raw material needed for production is the African star apple fruit, other raw materials such as sugar, citric acid are needed in various quantities. The major component needed for this process as stated earlier is the African star apple fruit which constitute $66.41 \%$ of the active ingredient needed for the formulation of the juice blend. The packaging material consider for this juice blend product is the Tetra Pak package which constitute a major cost of $2.53 \times 10^{8}$ for $100 \%$ plant utilization at 330 days. At a production rate of 100 tetrapack/min for 8 production hours, and $500 \mathrm{ml}$ of product/Tetrapak, a total of 48000 units $(100$ Tetra Pak $\times 60 \mathrm{~min} \times 8 \mathrm{~h}$ of actual production time per day) of products will produced a day $(=24000 \mathrm{~L}$ of juice per day). Other ingredients such as sugar, pectin, citric acid, ascorbic acid (Table 2) are required in smaller quantities when compared to the major component needed for the production. The major component (African star apple fruit) translates to 10 tonnes per day and 3300 tonnes for a 330-day production cycle. As production days decrease, the cost of production factors such as raw materials, general expenses and utilities were observed to also decrease. The same can also be said when the production plant was operated at different capacities of $100 \%, 85 \%$ and $70 \%$. These figures are reflected in Table 4 and 5. This is expected as more production days and a higher production capacity implies a higher demand for production resources which will drive the cost of production up. However, this also implies a higher production rate of finished products which tends to drive the products price down, increase sales and improve profit margins.

Cost such as labour, maintenance and depreciation remains unchanged. This is based on the assumption that the operators are regular salary earners and not casual laborers (if the labour were to be paid daily, the cost arising from this would also fluctuate with production days as the labour could readily be laid off when there is no production). Depreciation and maintenance cost were not also affected irrespective of the operational days of production or plant utilization capacities. This is due the production machineries and facilities needs to be maintained irrespective of their use duration and output capacities, likewise depreciation will always occur over time (as depreciation is not just a function of usage alone, but also of time). The annual operating cost increased by $7.73 \%$ and $20.24 \%$ when production days were reduced respectively from 330 days to 300 and 250 days. This had an impact on the production cost of a unit pack $(500 \mathrm{ml})$ of the Agbalumo juice driving up the price by $1.52 \%$ when production days was reduced from 330 to 300 days and $5.17 \%$ when production days was reduced to a further 250 days. This had an effect on the profit margin, reducing it proportionally downwards and increasing the unit selling price. This is attributed to certain general expenses that are incurred whether the production plant is producing or not. Varying plant utilization capacity as shown in Table 5 also had an effect on the annual cost of production, product unit cost, selling price and profit margin. Product cost per unit decreased by $0.21 \%$ as plant utilization decrease from $100 \%$ to $85 \%$. However, it was observed that the product cost for plant utilization at $85 \%$ and $70 \%$ 
remains the same (37.48 Naira). The implication of this is that new entrants into this industry should start production at $70 \%$ capacity instead of $100 \%$ for 330 days which is more viable economically. This will aid in studying and avoiding surplus production to market requirement and wastage.

The sensitivity of product price as a function of the number of operating days was tested. The results in Table 4 indicated that the fixed capital and some variable operating costs which are a function of the fixed capital did not change, while costs such as raw materials, utilities etc. increases as the number of production days and plant utilities decreases.

The IRR as an economic index of a project is acceptable when the IRR is equal to or greater than the minimum acceptable rate and rejected when the IRR is lower (Akanbi and Taiwo, 1999). The IRR for the Agbalumo fruit juice production plant which ranges from 57.70 - $61.67 \%$ under the various processing condition and at different operational days (250, 300 and 330) are therefore acceptable. The IRR reduces by $1.33 \%$ when production days were reduced from 330 to 300 days and $3.97 \%$ when reduced further to 250 days. Positive NPV values were obtained for several operating conditions (i.e. number of days and plant capacity), though the values decreased both with decrease in plant utilization capacities and number of production days. The higher IRR for plant utilization at $100 \%$ and 330 production operating days suggest that operation under this two condition is more robust and will be profitable even at higher rates even though a plant utilization capacity of
$70 \%$ for 330 operating days will be more economical and flexible for startup manufacturers as can be seen in Table 4 and Table 5 in terms of operating cost, unit price and profit. An investment is assumed profitable if the NPV exceeds the initial investment outlay (Lee et al., 1988; Akanbi and Taiwo, 1999). The fixed capital for the plant is $2.71 \times 10^{8}$. All reported NPV exceed this initial investment except when the plant is operated at $85 \%\left(2.49 \times 10^{8}\right)$ and $70 \%$ capacity $\left(1.73 \times 10^{8}\right)$. The result in Table 4 and Table 5 indicates that it is more profitable to operate the plant at $70 \%$ capacity for 330 than at $100 \%$ capacity for 330 days. These were reflected in the price per unit, IRR and NPV calculated values for the various operating conditions.

Table shows the Market price of African star apple juice at different profit margins for 330 days production timeline. At $30 \%$ selling profit price (for a 330 plant operational time frame), a $500 \mathrm{ml}$ Tetra Pak of African star apple juice will cost 48.83. Taking into consideration the price of other juice product in the market that sells on the average of $200 / 500 \mathrm{ml}$ Tetra Pak wholesaler price (such as yoghurt and orange juice), prospective manufacturer of Agbalumo juice can sell the product at $300 \%$ profit selling price which is set at a unit price at 150.24 which is still below the wholesale price of other juice product in the market. This prospective profit margin at $300 \%$ profit makes the production of this juice very lucrative when compared to the unit cost other products in the same competitive niche.

Table 4 Summary of the economic analysis for the production of African star apple juice in 500ml Tetra Pak at 100\% plant capacity utilization for different number of days in the year

\begin{tabular}{|c|c|c|c|}
\hline \multirow{2}{*}{ Parameters } & \multicolumn{3}{|c|}{ Estimate costs ( $\mathrm{N})$} \\
\hline & 330 & 300 & 250 \\
\hline Raw materials & $3.93 \times 10^{8}$ & $3.57 \times 10^{8}$ & $2.98 \times 10^{8}$ \\
\hline (Food materials) & $4.91 \times 10^{7}$ & $4.46 \times 10^{7}$ & $3.72 \times 10^{7}$ \\
\hline (Tetra pack) & $2.53 \times 10^{8}$ & $2.30 \times 10^{8}$ & $1.92 \times 10^{8}$ \\
\hline (Tetrapak Cartons) & $9.50 \times 10^{6}$ & $8.64 \times 10^{6}$ & $7.20 \times 10^{6}$ \\
\hline (Shrink pack) & $7.92 \times 10^{6}$ & $7.20 \times 10^{6}$ & $6.00 \times 10^{6}$ \\
\hline Utilities & $6.15 \times 10^{6}$ & $5.59 \times 10^{6}$ & $4.67 \times 10^{6}$ \\
\hline (Diesel) & $4.78 \times 10^{6}$ & $4.35 \times 10^{6}$ & $3.63 \times 10^{6}$ \\
\hline (Electrical \& Steam) & $1.37 \times 10^{6}$ & $1.24 \times 10^{6}$ & $1.04 \times 10^{6}$ \\
\hline Maintenance & $2.71 \times 10^{7}$ & $2.71 \times 10^{7}$ & $2.71 \times 10^{7}$ \\
\hline Labour & $6.96 \times 10^{6}$ & $6.96 \times 10^{6}$ & $6.96 \times 10^{6}$ \\
\hline Depreciation & $2.71 \times 10^{7}$ & $2.71 \times 10^{7}$ & $2.71 \times 10^{7}$ \\
\hline Annual Operating Cost & $5.95 \times 10^{8}$ & $5.49 \times 10^{8}$ & $4.74 \times 10^{8}$ \\
\hline Product cost/ $500 \mathrm{ml}$ Tetra Pack & 37.56 & 38.13 & 39.50 \\
\hline Selling price@ 30\% profit & 48.83 & 49.57 & 51.35 \\
\hline Profit & $1.78 \times 10^{8}$ & $1.65 \times 10^{8}$ & $1.42 \times 10^{8}$ \\
\hline Before tax earning & $2.05 \times 10^{8}$ & $1.92 \times 10^{8}$ & $1.69 \times 10^{8}$ \\
\hline Tax & $2.91 \times 10^{7}$ & $2.52 \times 10^{7}$ & $1.83 \times 10^{7}$ \\
\hline Cash flow & $1.76 \times 10^{8}$ & $1.67 \times 10^{8}$ & $1.51 \times 10^{8}$ \\
\hline NPV & $4.67 \times 10^{8}$ & $4.29 \times 10^{8}$ & $3.62 \times 10^{8}$ \\
\hline $\operatorname{IRR}(\%)$ & $61.67 \%$ & $60.34 \%$ & $57.70 \%$ \\
\hline
\end{tabular}


Table 5 Summary of the economic analysis for the production of African star apple juice in 500ml Tetra Pak for 330 days in the year at different plant capacity utilization

\begin{tabular}{l|ccc}
\hline \multirow{2}{*}{ Parameters } & \multicolumn{3}{c}{ Estimate costs (N) } \\
\cline { 2 - 4 } & $100 \%$ & $85 \%$ & $2.75 \times 10^{8}$ \\
\hline Raw materials & $3.93 \times 10^{8}$ & $3.34 \times 10^{8}$ & $3.43 \times 10^{8}$ \\
(Food materials) & $4.91 \times 10^{8}$ & $4.17 \times 10^{8}$ & $1.77 \times 10^{8}$ \\
(Tetra Pak) & $2.53 \times 10^{8}$ & $2.15 \times 10^{8}$ & $6.65 \times 10^{6}$ \\
(Tetra Pak Cartons) & $9.50 \times 10^{6}$ & $8.08 \times 10^{6}$ & $5.54 \times 10^{6}$ \\
(Shrink pack) & $7.92 \times 10^{6}$ & $6.73 \times 10^{6}$ & $4.31 \times 10^{6}$ \\
Utilities & $6.15 \times 10^{6}$ & $5.22 \times 10^{6}$ & $3.35 \times 10^{6}$ \\
(Diesel) & $4.78 \times 10^{6}$ & $4.06 \times 10^{6}$ & $9.59 \times 10^{5}$ \\
(Electrical \& Steam) & $1.37 \times 10^{6}$ & $1.16 \times 10^{6}$ & $2.71 \times 10^{7}$ \\
Maintenance & $2.71 \times 10^{7}$ & $2.71 \times 10^{7}$ & $6.96 \times 10^{6}$ \\
Labour & $6.96 \times 10^{6}$ & $6.96 \times 10^{6}$ & $2.71 \times 10^{7}$ \\
Depreciation & $2.71 \times 10^{7}$ & $2.71 \times 10^{7}$ & $4.17 \times 10^{8}$ \\
Annual Operating Cost & $5.95 \times 10^{8}$ & $5.06 \times 10^{8}$ & 37.48 \\
Product cost/ 500ml Tetra Pak & 37.56 & 37.48 & 48.72 \\
Selling price@ 30\% profit & 48.83 & 48.72 & $1.24 \times 10^{8}$ \\
Profit & $1.78 \times 10^{8}$ & $1.50 \times 10^{8}$ & $1.51 \times 10^{8}$ \\
Before tax earning & $2.05 \times 10^{8}$ & $1.77 \times 10^{8}$ & $4.53 \times 10^{7}$ \\
Tax & $2.91 \times 10^{7}$ & $5.31 \times 10^{7}$ & $1.51 \times 10^{8}$ \\
Cash flow & $1.76 \times 10^{8}$ & $1.67 \times 10^{8}$ & $1.73 \times 10^{8}$ \\
NPV & $4.67 \times 10^{8}$ & $2.49 \times 10^{8}$ & $45.69 \%$ \\
IRR (\%) & $61.67 \%$ & $51.43 \%$ & \\
\hline An & &
\end{tabular}

An exchange rate of 201.55 to US\$1 as of September 2015 was assumed

From an economic point of view, it is best to operate the production plant for 330 days than at either 300 or 250 days. This is because, factors such as depreciation, labour and maintenance remains the same irrespective of the number of operational days. Also, operation for $>330$ days will help to prevent rust from setting into production equipment's that are majorly made from steel and metals. Also, idle time is reduced, production process is sustained and continuous inventory can be easily made on raw materials and product supply thus reducing wastage.

Table 7 shows the payback time and profitability percent of different operating days. It can be seen that if the production plant is operated for 330 days, the payback time and profitability percent is expected to be 4.77 years and $20.98 \%$. This appears to be lower figures when compare to values obtained for 300 days (4.75 years $/ 21.06 \%$ ) and 250 days (4.76years $/ 21.03 \%)$.

The major limitation to the production of this juice is the non-availability of the fruit (African star apple) all through the year and the need to operate the production plant for at least 330 days at $70-85 \%$ plant capacity in the year. Hence, a means of preserving the fruit during its harvest season is necessary.

Table 6 Market price of African star apple juice at different profit margins for 330 days production timeline

\begin{tabular}{l|c}
\hline \multicolumn{1}{c|}{ Profit Margin } & Selling price $(\mathrm{N}) / 500 \mathrm{ml}$ \\
\hline Cost price +\%profit & Tetra Pak line \\
30 & 48.83 \\
40 & 52.58 \\
50 & 56.34 \\
\hline
\end{tabular}

An exchange rate of N 201.55 to US\$1 as of September 2015 was assumed

\section{Conclusion}

This study evaluated the economic performance of the production of "African star apple" fruit juice in a $500 \mathrm{ml}$ Tetrapak under different production conditions such as number of days and capacity utilization. The NPV and IRR values indicated that the number of production days should not be less than 250 days while also indicating that a plant utilization of 70 and $85 \%$ is desirable and economically viable when operated at 330 days than when operated at $100 \%$. The analysis indicated that a unit pack of this juice can be sold for over $300 \%$ profit price instead of the proposed $30 \%$ profit selling price when compared to the price of other juice product of the same packaging material and volume. It is therefore recommended that the prospective manufacturer embark on a long term project of having its own Agbalumo plantation farm where the fruit can be sourced directly from. This will help in reducing the challenges of getting the fruits for production process while ensuring long term sustenance of industrial production process and maximizing profit. Market and local farms around should be viewed as short term alternative for the fruit supply.

Table 7 Payback time and profitability percent for 330 days production rate

\begin{tabular}{c|cc}
\hline $\begin{array}{c}\text { No of Days of } \\
\text { Operation }\end{array}$ & $\begin{array}{c}\text { Payback } \\
\text { Time(Years) }\end{array}$ & Profitability (\%) \\
\hline 330 & 4.77 & 20.98 \\
300 & 4.75 & 21.06 \\
250 & 4.76 & 21.03 \\
\hline
\end{tabular}




\section{Acknowledgements}

This work was made possible through the mentorship and training in the field of Agricultural Economics and Analysis received from Professor K.A. Taiwo of the Department of Food Science and Technology, Obafemi Awolowo University. Appreciation also goes to $\mathrm{Mr}$. Kolawole Temitope for his review criticisms of this work.

\section{References}

Abou -Fadel OS , Miller LT. 1983. Vitamins retention, colour, and texture in thermally processed green beans and royal Ann cherries packed in pouches and cans. J of Food Sci 48: 920-923.

Adepoju OT, Adeniji PO. 2012. Nutrient composition and micronutrient potential of three wildly grown varieties of African star apple (Chrysophyllum albidum) from Nigeria. Afri $\mathrm{J}$ of Food Sci 6(12): 344-351.

Adewusi HG, Bada SO .1997. Preliminary information on the Ecology of Chrysophyllum albidum in West and Central Africa: in proceedings of a national workshop on the Potentials of the star apple in Nigeria, pp. 16-25.

Ajewole K, Adeyeye A. 1991. Seed oil of white star apple (Chrysophyllum albidum) Physiochemical characteristics and fatty acid composition. J Sci Food \& Agric 54: 313- 315.

Akanbi CT, Taiwo KA. 1999. Economic analysis of the production of ready-to-eat 'Gbegiri' bean mix powder. Technovation 19:747-753.
Amusa NA, Ashaya OE, Oladapo MO. 2003. Bio-deterioration of the African Star Apple (Chrysophyllum albidum) in storage and the effect on its food value. Afri J Biotech 2(3): 56-59.

Barry PJ, Hopkin JA and Baker CB. 1983 . Financial Management in Agriculture, 3rd Ed. The Interstate Printers and Publishers, Inc., Danville, IL.

Cabes, LJ. 1985. Plastic packaging used in retort processing: Control of key parameters. Food Tech 39 (12): 57-60.

Coulson JM, Richardson JF. 2005. Chemical Engineering, Vol. 6, Fourth Edition. Pergamon Press, New York.

DeGarmo EP, Canada JR, Sullivan WG. 1979. Engineering Economy, 6th ed. MacMillan Publishing Co., Inc., New York.

Peters M, Timmerhaus K, West R.2003. Plant Design and Economics for Chemical Engineers. McGraw-Hill, Boston.

ICRAF. 2007. Chrysophyllum albidum, International center for research in agro-forestry.Kenya.3p.

Lee WF, Boehije, MD, Nelson AG, Murray WG. 1988. Agricultural Finance, 8th Ed. Iowa State University Press, America.

Tang J, Wei H, Jun F,Zhixiang, L. 2016. Techno-economic evaluation of a combined bioprocess for fermentative hydrogen production from food waste. Bioresource Technology 202. 107112

Taiwo KA, Akanbi CT, Ajibola OO. 1997. Production of cowpeas in tomato sauce: Economic comparison of packaging in canning and retort pouch systems. J Food Proc Eng. 20:337-348.

UNIDO Technology Manual. 2004. Small-Scale Fruit and Vegetable Processing. Vienna

Ureigho UN, Ekeke BA. 2010. Nutrient Values of Chrysophyllum Albidum Linn African Star Apple as a Domestic Income Plantation Species. Afri Res Rev 4(2): 50-56.

Zacharias, BM, George, D.S. 2008. Food Plant Economics. CRC Press, New York. 